\title{
Diário do Contador de Histórias da Associação Viva e Deixe Viver
}

\author{
Cimino, Valdir; Sendin, M.M.; Cimino, V. \\ Associação Viva e Deixe Viver — valdir.cimino@uol.com.br
}

Desde a sua fundação em 1997 a Associação Viva e Deixe Viver implantou o ferramental denominado "Diário do Contador de Histórias", que tem por objetivo registar as atividades desenvolvidas por seus voluntários com o proposito da melhoria nas relações interpessoais com as crianças e adolescentes atendidas pela instituição, suas famílias e os prossionais da saúde. CONSTRUÇÃO de HISTÓRIAS uma história oferece à criança novos modos de pensar sobre seus sentimentos difíceis. a história apresenta sentimentos que já foram rigorosamente pensados pelo autor e isso é extremamente útil para a criança, que teve esses sentimentos problemáticos sem conseguir pensar direito sobre eles. a história permite que a criança assuma um novo modo de ver a situação, de conhecê-la ou de se relacionar com alguém ou com algo em sua vida. com isso ela tem tempo para re-etir sobre sua situação, seus sentimentos e seu modo de ser. METODOLOGIA Registo sobre as percepções observadas pelo " contador de Histórias voluntário " sobre a relação do tempo qualicado doado no acolhimento de pacientes, conviventes e prossionais da saúde. a equipe de pesquisadores "contadores de Histórias" utilizou a metodologia de pesquisa qualitativa e quantitativa através de caderno denominado "diário do Contador de Histórias. Pretende-se compreender o histórico de vida da criança, como desenvolveu o brincar e se possui o hábito de ouvir histórias. CONCLUSÕES PRELIMINARES - COORDENAÇÃO MOTORA: As crianças desenvolveram habilidade manual: construção de aviõezinhos de papel, câmera de filmar, dobraduras (tipo origami) colagem, pintura (alguns já possuem o dom), desenho, recortes de revistas, equilíbrio (empilhamento e construção de edifícios com blocos); pular corda; jogos ao ar livre: basquete, bola. - RACIOCÍNIO LÓGICO/ INTELIGÊNCIA: Desenvolvimento da: esperteza, atenção, observação; comunicação, concentração, participação nas atividades e capacidade de interagir com outras crianças e/ou contadoras (es); capacidade de reprodução do que foi narrado e/ou contado com coerência; de dar continuidade à história (jogo eu conto); aumento do vocabulário, fluência verbal, desinibição, espontaneidade. Auxílio na dicção. Participação ativa nas brincadeiras e leituras. Resolução de palavras cruzadas. Extroversão, diminuição da timidez e do medo. • AFETIVIDADE: Abraços, beijos, carinhos, presentear contadores e/ou médicos (as) enfermeiras (os) com desenhos ou flores; aumento da alegria, diminuição da agressividade; bondade, solidariedade. OBS: 1) Algumas crianças com necessidades especiais, embora mais tímidas, acabaram se envolvendo e curtindo as brincadeiras e histórias. 2) Outras, talvez com problemas familiares, desenhavam ou falavam coisas negativas, como por exemplo: revólver, morte, assassinatos; (a contadora preferiu não tecer comentários por não saber exatamente do que se tratava). 3) Crianças que a princípio recusaram a contação ou brincadeira, com o passar do tempo foram se aproximando e acabaram por participar. 4) Parentes (especialmente mães), nem sempre participavam, mas algumas se interessavam, participavam e estimulavam as crianças para ouvirem a contação de histórias ou entrar na brincadeira. 5) Profissionais quase não participaram, mas muitos ouviram a contação e/ou observaram a brincadeira. Outros estimularam a participação das crianças.

Cimino, Valdir; Sendin, M.M.; Cimino, V.. Diário do Contador de Histórias da Associação Viva e Deixe Viver. In: Anais do Congresso Internacional de Humanidades \& Humanização em Saúde [= Blucher Medical Proceedings, num.2, vol.1]. São Paulo: Editora Blucher, 2014. ISSN 2357-7282 DOI 10.5151/medpro-cihhs-10533 